\title{
PERLINDUNGAN HUKUM TERHADAP ANAK KORBAN BULLYING DI LINGKUNGAN SEKOLAH
}

\author{
Oleh: \\ Sari Damayanti \\ Email : sari.d@universitasmulia.ac.id \\ Universitas Mulia Balikpapan \\ Okta Nofia Sari \\ Email : Oktanofia@universitasmulia.ac.id \\ Universitas Mulia Balikpapan \\ Kesuma Bagaskara \\ Email: kesumabagaskara@ students.universitasmulia.ac.id \\ Universitas Mulia Balikpapan
}

\begin{abstract}
Abstrak
Perlindungan Anak merupakan segala kegiatan untuk menjamin dan melindungi Anak dan hak-haknya agar dapathidup, tumbuh, berkembang, dan berpartisipasi secara optimal sesuai dengan harkat dan martabat kemanusiaan, serta mendapat perlindungan dari kekerasan dan diskriminasi. Pelaksanaan perlindungan anak tidak hanya dilakukan oleh orang tua namun juga harus dilakukan oleh semua elemen dari pihak sekolah ataupun masayakat. Kerja sama dalam melakukan perlindungan terhadap anak akan memberikan dampak positif dalam tumbuh kembangnya. Pihak sekolah juga dapat melakukan pembentukan karakter terhadap siswanya serta memberikan sanksi terhadap pelaku tindak pidana bullying agar pelaku jera da tidak mengulangi perbuatannya lagi.
\end{abstract}

Kata Kunci : Perlindungan, Anak, Bullying

\begin{abstract}
Child Protection is all activities to guarantee and protect children and their rights so that they can live, grow, develop and participate optimally in accordance with human dignity and protection from violence and discrimination. The implementation of child protection is not only carried out by parents but also must be carried out by all elements of the school or community. Cooperation in protecting children will have a positive impact on their growth and development. The school can also build character for students and impose sanctions on perpetrators of criminal acts of bullying so that the perpetrators are deterred from repeating their actions.
\end{abstract}

Keyword : Protection, Children, Bullying 


\section{PENDAHULUAN}

\subsection{Latar Belakang}

Perkembangan hukum yang terjadi di Indonesia sudah sangat bervariatif dalam berbagai bidang. Melihat perkembangan yang sudah ada maka bentuk kejahatan juga dimungkinkan tidak hanya terjadi dilingkungan masyarakat akan tetapi juga masuk kedalam lingkungan generasi muda yang saat ini dikenal sebagai generasi muda milenial. Kejahatan yang sangat marak terjadi dalam lingkungan remaja adalah bullying. Tindakan bullying yang dapat dilakukan oleh pelaku sangatlah beragam mulai dari bullying verbal, bullying fisik maupun sampai dengan perkembangan teknologi yaitu cyber bullying.

Bullying verbal merupakan tindakan bullying yang dilakukan dengan cara mengejek fisik seseorang, merendahkan martabat seseorang hingga dengan menghina keluarga seseorang. Hal ini tanpa kita sadari sering dilakukan dalam keadaan bercanda atau senda gurau namun kita juga tanpa menyadari telah menyakiti perasaan atau psikis seseorang. Bullying Fisik merupakan tindakan dengan melakukan kekerasan kepada orang yang lebih lemah dengan sehingga menimbulkan rasa sakit atau cacat, sedangkan cyber bullying yang marak terjadi di dunia maya yaitu dengan cara berkomentar pada postingan seseorang di media sosial. Cyber bullying tidak perlu mengenal secara dekat atau memiliki hubungan dengan korbannya namun hanya sebatas berteman di sosial media mereka dapat melakukan cyber bullying dimanapun dan kapanpun.

Kasus bullying sudah banyak sekali terjadi di negara kita hingga yang sangat menyedihkan apabila tindakan bullying tersebut dapat merengut nyawa seseorang baik itu korban maupun pelaku bullying. Pencegahan bullying harus dilakukan baik dimulai dari lingkungan keluarga, lingkungan sekolah, lingkungan pekerjaan sampai lingkungan pertemanan. Perlindungan terhadap anak sangat diperlukan dikarenakan apabila terjadi tindakan yang dapat mempengaruhi perkembangan diri pada anak. Semua lingkungan harus bersinergi untuk dapat menanamkan sikap yang terpuji dengan saling menghormati dan menghargai antar sesama manusia.

\subsection{Rumusan Masalah}

1. Bagaimanakah karakteristik tindakan bullying yang dapat terjadi pada anak?

2. Bagaimana perlindungan hukum yang dapat diberikan kepada korban bullying di lingkungan sekolah? 


\section{METODE PENELITIAN}

Penelitian merupakan suatu sarana pokok dalam pengembangan ilmu pengetahuan maupun teknologi, hal ini disebabkan karena penelitian bertujuan untuk mengungkapkan kebenaran secara sistematis dan konsistensi. ${ }^{1}$ Penelitian hukum adalah suatu proses untuk menentukan aturan hukum, prinsip-prinsip hukum maupun doktrin-doktrin hukum guna menjawab isu hukum yang dihadapi. ${ }^{2}$ Penelitian untuk penulisan ini menggunakan tipe penelitian yuridis normatif (Legal Research). Tipe penelitian yuridis normatif adalah penelitian yang dilakukan dengan meneliti bahan pustaka atau data sekunder belaka. Penelitian hukum normatif atau kepustakaan tersebut mencakup penelitian terhadap asasasas hukum, penelitian terhadap sistematik hukum, penelitian terhadap taraf sinkronisasi vertikal dan horizontal, perbandingan hukum dan sejarah hukum. ${ }^{3}$

\footnotetext{
1 Soerjono Soekanto dan Sri Mamudji, Penelitian Hukum Normatif (Suatu Tinjauan Singkat), RajaGrafindo Persada, cetakan ke-16, Jakarta, 2014, Hlm.1.

2 Peter Mahmud Marzuki, Penelitian Hukum, Kencana Prenada Media, Jakarta, 2011, Hlm.35.

${ }^{3}$ Soerjono Soekanto dan Sri Mamudji , Op. cit .Hlm. 13.
}

\section{PEMBAHASAN}

\subsection{Karakteristik Tindakan Bullying Yang Dapat Terjadi Pada Anak}

Perilaku bullying merupakan tindakan negatif yang dilakukan secara berulang oleh beberapa oknum yang bersifat menyerang karena adanya ketidakseimbangan kekuatan antara pohak yang terlibat baik itu merupakan serangan emosional, verbal ataupun fisik.

\section{A. Pihak yang terlibat dalam kasus Bullying}

\section{Bullies (Pelaku)}

Pelaku Bullying yaitu sesorang yang secara fisik atau verbal melukai orang lain yang dilakukan secara berulangulang. Pelaku bullying cenderung mendominasi orang lain dan memiliki kemampuan sosial dan pemahaman akan emosi orang lain yang sama.;

Menurut Stephenson dan Smith (dalam Sullivan, 2000), tipe pelaku bullying antara lain:

(1) tipe percaya diri, secara fisik kuat, menikmati agresifitas, merasa aman dan biasanya populer,

(2) tipe pencemas, secara akademik lemah, lemah dalam berkonsentrasi, kurang populer dan kurang merasa aman, dan

(3) pada situasi tertentu pelaku bullying bisa menjadi korban bullying. 
Menurut Astuti (2008) pelaku

bullying biasanya agresif baik secara verbal maupun fisikal, ingin popular, sering membuat onar, mencari-cari kesalahan orang lain, pendendam, iri hati, hidup berkelompok dan menguasai kehidupan sosial di sekolahnya. Selain itu pelaku bullying juga menempatkan diri di tempat tertentu di sekolah atau di sekitarnya, merupakan tokoh popular di sekolahnya, gerak geriknya sering kali dapat ditandai dengan sering berjalan di depan, sengaja menabrak, berkata kasar, dan menyepelekan/ melecehkan.

\section{Victims (Korban)}

Victims adalah korban bullying atau orang yang dibully oleh bullies. Menurut Byrne dibandingkan dengan teman sebayanya yang tidak menjadi korban, korban bullying cenderung menarik diri, depresi, cemas dan takut akan situasi baru ${ }^{4}$. Seseorang bisa menjadi korban bullying karena sering terlihat sendiri dan punya kepercayaan diri rendah. Namun, halhal lain juga bisa menjadi alasan, kenapa seseorang bisa menjadi korban bullying. Korban bullying biasanya merupakan anak yang berbeda dengan anak lainnya, seperti

\footnotetext{
${ }^{4}$ Haynie, D. L dkk , 2001 , "Bullies, Victims, and Bully/Victims: Distinct Groupsof At-Risk Youth,
}

anak yang ras, agama, bahkan orientasi seksualnya dipandang inferior sehingga layak dihina, anak baru, anak termuda, atau bisanya lebih kecil disuatu lingkungan sekolah, bahkan anak cerdas, berbakat, atau memiliki kelebihan dijadikan sasaran karena ia unggul.

3. Bystander (Orang yang menyaksikan bullying)

Bystander adalah orang yang menyaksikan perbuatan bullying. Bystander bisa dikelompokkan menjadi tiga, diantaranya :

a. Defender

Defender adalah orang yang menyaksikan bullying. Saat melihat perbuatan bullying, orang ini membantu korban agar tidak dibully lagi oleh bullies.

b. Reinforce

Reinforcer adalah orang yang menyaksikan bullying. Saat melihat perbuatan bullying, bukannya membantu korban ia malah membantu bullies untuk ikut membully korban.

c. Outsider

Outsider adalah orang yang menyaksikan bullying. Saat melihat perbuatan bullying, ia tidak membantu korban atau bahkan ikut membully korban, 
namun ia lebih memilih untuk diam dan pura-pura tidak tahu.

\section{B. Faktor Penyebab Terjadinya Bullying}

1.Keluarga

Faktor terdekat dari penyebab terjadinya bullying yaitu keluarga, biasanya pelaku bullying seringkali berasal dari keluarga yang bermasalah, seperti orang tua yang sering menghukum anaknya secara berlebihan, orang tua yang selalu bertengkar didepan anaknya, kemudian anak akan mempelajari dan mengamati perilaku yang dilakukan oleh orang tua mereka kemudian menirunya terhadap teman-temannya.

2. Sekolah

Faktor selanjutnya yaitu sekolah, karena pihak sekolah sering menyepelekan bahkan mengabaikan perilaku bullying. Akibatnya, para pelaku bullying akan terus melakukan bullying kepada korban karena tidak adanya sikap tegas terhadap pihak sekolah dan tidak ada sikap dalam melindungi para korban bullying.

3. Kelompok Bermain

Faktor selanjutnya yaitu kelompok bermain, karena biasanya anak melakukan bullying dalam usaha untuk membuktikan bahwa mereka bisa masuk dalam kelompok bermain tertentu, meskipun mereka sendiri merasa tidak nyaman dengan perilaku bullying yang mereka lakukan.

4. Kondisi Lingkungan Sosial

Faktor selanjutnya yaitu kondisi lingkungan sosial, salah satunya yaitu kemiskinan. Bullies atau pelaku bullying akan melakukan apa saja demi memenuhi kebutuhan hidupnya, contohnya seperti pemalakan, pemerasan, dll.

5. Film dan Tayangan Televisi

Faktor selanjutnya yaitu dari film dan tayangan televisi. Para pelaku bullying biasanya meniru adeganadegan kekerasan yang terdapat pada film dan tayangan televisi entah dari geraknya ataupun kata-katanya.

\section{Jenis-Jenis Bullying}

\section{BullyingSecara Emosional}

Bullying secara emosional biasanya dilakukan pelaku dengan tujuan agar korbannya merasa terganggu secara mental. Bullying secara emosional tidak bisa dianggap sepele karena perilaku bullying ini dapat membuat korbannya depresi. Contoh bullying secara emosional diantaranya :

a. Menyebarkan Gosip

Perilaku Bullying ini yang sering ditemukan di seluruh kalangan, termasuk di lingkungan anak, Biasanya para pelaku menyebarkan 
berita-berita yang tidak benar yang merujuk kepada korban. Dampaknya korban akan dijauhi dan menjadi bulan-bulanan.

b. Menghasut

Perilaku Bullying ini juga sering ditemukan, biasanya para pelaku menghasut korban agar terpancing dan marah. Dampaknya korban akan terpancing dan melakukan tindakan yang tidak terpuji.

\section{BullyingSecara Verbal}

Bullying secara verbal atau Verbal Bullying biasanya sering ditemukan dilingkungan anak, dan bahkan tanpa sadar dilakukan oleh pelaku. Pelaku biasanya menggunakan kara-kata kasar yang merendahkan dan membuat korban menjadi tidak percaya diri bahkan depresi. Contoh bullying secara verbal diantaranya :

a. Menghina/Mengejek/Mencela

Pelaku biasanya secara berlebihan mengatakan hal yang merendahkan, dan meremehkan dengan maksud menyakiti perasaan korban atau mempermalukan korban didepan orang lain.

b. Memberi Panggilan Nama

Pelaku biasanya memberikan nama atau julukan kepada korban yang sifatnya merendahkan dan membuat malu dan sampai tidak percaya diri kepada korban. c. Mengintimidasi

Pelaku biasanya mengintimidasi dalam artian mengancam korban agar takut bahkan tunduk kepada pelaku.

d. Memaki

Pelaku biasanya mengucapkan kata-kata keji, tidak pantas untuk menyatakan kemarahan atau kejengkelan terhadap korban.

\section{Bullying Secara Fisik}

Bullying secara fisik atau Physical Bullying adalah jenis perilaku bullying yang paling jelas dan dapat dilihat jika terjadi dilingkungan anak. Pelaku biasanya memberikan kekerasan secara fisik yang membuat korban takut dan menuruti apa yang pelaku inginkan. Diantaranya memukul, menendang, mencakar, menggigit, meludah kearah korban hingga menimbulkan luka fisik atau cidera. Jenis bullying ini paling berbahaya karena selain memberi dampak ke fisik korban juga dapat memberi dampak ke psikis korban, dan akan menimbulkan trauma terhadap korban. 
3.2 Perlindungan Hukum Yang Dapat Diberikan Kepada Korban Bullying di Lingkungan Sekolah

Negara Indonesia adalah negara hukum yang berdasarkan Pancasila dengan menjunjung tinggi nilai-nilai moral, etika, akhlak mulia, dan kepribadian luhur bangsa, beriman dan bertakwa kepada Tuhan Yang Maha Esa, menghormati kebinekaan dalam kehidupan bermasyarakat, berbangsa, dan bernegara, serta melindungi harkat dan martabat setiap warga negara. ${ }^{5}$ Suatu tindak pidana atau perbuatan pidana biasanya disebabkan oleh banyak faktor, tidak ada faktor penyebab tunggal. Faktor penyebabnya dapat bermacammacam yaitu karena faktor ekonomi, rumah tangga, dan keluarga, maupun pengaruh lingkungan, terutama lingkungan di luar rumah. Kebanyakan anak sering bermain di luar rumah, berkumpul dengan temantemannya baik teman di sekitar rumah, teman satu sekolah atau teman satu kelompok. Mereka tidak menyadari bahwa di dalam pergaulannya mereka sering melupakan kaidah-kaidah dan hukum yang berlaku dalam masyarakat, sehingga lahirlah sifat-sifat tidak bermoral, kejam dan jahat.

Upaya penanggulangan kejahatan secara garis besar dapat dibagi dua yaitu melalui jalur penal (hukum pidana) atau

5 Gatot Soepromono, 2000, Hukum Acara Pengadilan Anak, PT Djambatan, Jakarta, , hlm.2 melalui jalur nonpenal (bukan atau di luar hukum pidana). Upaya penanggulangan melalui jalur penal lebih menitik beratkan pada sifat represif (penindasan atau pemberantasan atau penumpasan) sesudah kejahatan terjadi, sedangkan jalur non penal lebih menitik beratkan pada sifat preventif (pencegahan atau pengendalian) sebelum kejahatan terjadi.

Satjipto Raharjo mendefinisikan Perlindungan Hukum adalah memberikan pengayoman kepada hak asasi manusia yang dirugikan orang lain dan perlindungan tersebut diberikan kepada masyarakat agar mereka dapat menikmati semua hak-hak yang diberikan oleh hukum. ${ }^{6}$ Menurut Philipus M. Hadjon bahwa Perlindungan Hukum adalah perlindungan akan harkat dan martabat, serta pengakuan terhadap hak-hak asasi manusia yang dimiliki oleh subyek hukum berdasarkan ketentuan hukum dari kesewenangan. Menurut CST Kansil Perlindungan Hukum adalah berbagai upaya hukum yang harus diberikan oleh aparat penegak hukum untuk memberikan rasa aman, baik secara pikiran maupun fisik dari gangguan dan berbagai ancaman dari pihak manapun. ${ }^{7}$

Upaya untuk mencegah dan menanggulangi tindak pidana atau kejahatan ini

6 Salim HS,dkk, Penerapan Teori Hukum Pada Tesis dan Desertasi,Raja Grafindo Persada, Jakarta, 2013, Hlm. 262

7 http://tesishukum.com/pengertian-perlindunganhukum-menurut-para-ahli/ di akses pada tanggal 24 Juli 2020 pada jam 12.39 wita 
termasuk dalam wilayah kebijakan kriminal (criminal policy) terdapat dua masalah sentral dalam kebijakan kriminal dengan meng-gunakan sarana penal (hukum pidana) ialah masalah penuntuan tentang $:^{8}$

1. Perbuatan apa yang seharusnya dijadikan tindak pidana;

2. Sanksi apa yang seharusnya dipergunakan atau dikenakan kepada si pelanggar.

Upaya Pencegahan terhadap anak sebagai pelaku berkaitan dengan perlindungan hukum sebagaimana menurut Lili Rasjidi dan I.B Wyasa Putra mengemukakan bahwa hukum dapat difungsikan tidak hanya mewujudkan kepastian tetapi juga menjamin perlindungan dan keseimbangan yang sifatnya tidak sekedar adaptif dan fleksibel namun juga prediktif dan antisipatif 9 . Kebijakan non penal merupakan hal yang sangat tepat untuk mencegah terjadinya tindak pidana yang dilakukan oleh anak. Anak merupakan generasi penerus bangsa, untuk itulah anak memperoleh perhatian yang luar biasa tidak saja oleh negara akan tetapi masyarakat dunia. Begitu pentingnya anak maka semua negara-negara di dunia berfikir untuk mencari bentuk alternatif penyelesaian yang terbaik untuk anak. Perhatian terhadap perlindungan anak di

8 Muladi dan Barda Nawawi, Teori-Teori dan Kejahatan Hukum Pidana, Alumni, Bandung, 2005, Hlm.160

${ }^{9}$ Abintoro Prakoso, Hukum Perlindungan Anak, Fakultas Hukum Universitas Jember, Jember, 2015,Hlm.3
Indonesia sendiri dapat ditelusuri mulai dari apa yang telah diamanatkan pembukaan Undang-Undang Dasar 1945 alinea ke-4 (empat), dari rumusan tersebut diketahui perhatian terhadap anak juga merupakan bagian dari tujuan negara.

Kejahatan saat ini sangat marak yang terjadi dalam lingkungan anak-anak dan yang sering kita jumpai saat ini adalah tindakan bullying atau bisa juga dengan intimidasi terhadap orang lain. Pelaku korban bullying biasanya melakukan tidak sendiri namun bisa berkelompok karena mereka merasa dirinya kuat atau berkuasa. Korban yang mereka incar adalah mereka yang memiliki kelemahan pada dirinya atau tidak memiliki kekuatan dalam lingkungan. Korban yang menerima tindakan bullying mereka biasanya akan merasa minder dan kurang percaya diri. Hal seperti inilah yang menjadi tugas para penegak perlindungan anak untuk memberikan perlindungan kepada korban. Perlindungan hukum bagi anak yang meliputi berbagai aspek yaitu ${ }^{10}$ :

a. Perlindungan terhadap hak-hak asasi dan kebebasan anak

Hak-hak anak merupakan bagian integral dari Hak Asasi Manusia berkaitan dengan peranan negara, maka tiap negara mengembankan kewajiban untuk melindungi, memenuhi, dan menghor-

10 Barda Nawawi, Beberapa Aspek Kebijakan Penegakan dan Pengembangan Hukum Pidana, Citra Aditya Bakti, Bandung, 1998, Hlm. 156. 
mati hak-hak anak, Berdasarkan kewajiban negara dimaksud maka sistem kesejahteraan anak dan keluarga diimplementasikan dalam kerangka kebijakan yang sifatnya kontinum dan tingkat makro sampai mikro. ${ }^{11}$

b. Perlindungan anak dalam proses peradilan

Anak-anak memiliki hak untuk tidak menjadi korban dalam proses peradilan pidana, mempunyai kewajiban sebagai hak untuk ikut serta menegakkan keadilan dalam suatu proses peradilan pidana sesuai dengan kemampuan mereka masing-masing untuk dibina agar mampu melaksanakan kewajibannya sebagai warga negara, anggota masyarakat yang baik oleh yang berwajib dalam arti luas; untuk melaksanakan kewajiban membina, mendampingi rekan-rekan sebayanya untuk melaksanakan hak dan kewajiban mereka secara rasional positif, bertanggungjawab dan bermanfaat dalam proses tersebut ${ }^{12}$.

c. perlindungan kesejahteraan anak (dalam lingkungan keluarga, pendidikan dan lingkungan sosial),

Sebagaimana diuraikan dalam Child and Family Services Review process (Child

\footnotetext{
${ }^{11}$ Mohammad Taufik Makarao dkk, 2013, Hukum Perlindungan Anak dan Penghapusan Kekerasan dalam Rumah Tangga, Jakarta: Rineka Cipta. Hlm 31

${ }^{12}$ Abintoro Prakoso, 2013, Pembaruan Sistem Peradilan Pidana Anak, Yogyakarta: Laksbang Grafika, Hlm 21
}

Welfare, For The Twenty-First Century, 2005), tiga variabel kesejahteraan dikonseptualisasikan dalam kerangka yang meliputi: 1)kesejahteraan dalam arti keluarga memiliki peningkatan kapasitas untuk memenuhi kebutuhan anak-anak mereka; 2)kesejahteraan dalam arti anak-anak dan remaja terpenuhi kebutuhan pendidikannya, dan 3)kesejahteraan dalam arti anak-anak dan remaja terpenuhi kebutuhan fisik dan kesehatan mental mereka. Adapun Undang-Undang Republik Indonesia Nomor 4 Tahun 1979 tentang Kesejahteraan Anak menyebutkan bahwa anak berhak atas kesejahteraan, perawatan, asuhan dan bimbingan berdasarkan kasih sayang baik dalam keluarganya maupun dalam asuhan khusus untuk tumbuh dan berkembang dengan wajar dimana orangtua bertanggung jawab atas kesejahteraan anak. Lebih lanjut dijelaskan bahwa kesejahteraan anak adalah suatu tata kehidupan dan penghidupan anak yang dapat menjamin pertumbuhan dan perkembangannya dengan wajar, baik secara rohani, jasmani, maupun sosial.

d. perlindungan anak dalam masa penahanan dan perampasan kemerdekaan,

Dalam Undang-Undang Nomor 11 Tahun 2012 tentang Sistem Peradilan Anak dijelaskan mengenai prosedur penangkapan dan penahanan anak 
dimana anak yang ditangkap wajib ditempatkan dalam ruang pelayanan khusus anak yang apabila belum tersedia maka yang bersangkutan wajib dititipkan di LPKS dan diperluakan secara manusiawi serta memperhatikan kebutuhan sesuai umurnya. Dan apabila anak memperoleh jaminan dari orang tua/ wali dan/atau lembaga bahwa anak tidak melarikan diri, tidak akan menghilangkan atau merusak barang bukti, dana tau tidak akan mengulangi tindak pidana, maka penahanan terhadap anak tidak boleh dilakukan. Adapun penahanan hanya dapat dilakukan terhadap anak yang telah berusia 14 (empat belas) tahun atau lebih dan diduga melakukan tindak pidana dengan ancaman pidana penjara 7 (tujuh) tahun atau lebih.

e. perlindungan anak dari segala eksploitasi (perbudakan, perdagangan anak, pelacuran, pornografi, perdagangan/ penyalahgunaan obat-obatan, memperalat anak dalam melakukan kejahatan dan sebagainya).

Terres des Hommes, sebuah organisasi perlindungan anak internasional, mendefinisikan eksploitasi terhadap anak secara lebih spesifik yaitu: “Anak-anak dianggap dieksploitasi ketika adanya profit yang dihasilkan dari kerentanan dan ketiadaan kekuasaan anak, terlepas apakah anak tersebut dipaksa untuk keuntungan orang lain ataupun berupa mereka memulai bekerja di usia yang terlalu muda maupun waktu yang panjang. Eksploitasi juga terjadi ketika anak bekerja di kondisi berbahaya dan tidak sehat, ketika mereka dibayar murah atau dipaksa untuk menjadi pekerja paksa, terikat hutang maupun perbudakan. $^{13}$

f. perlindungan terhadap anak-anak jalanan,

Dalam Pasal 34 Undang-Undang Dasar Negara Republik Indonesia Tahun 1945 disebutkan bahwa fakir miskin dan anak-anak yang terlantar dipelihara oleh negara. Mengacu pada asas kepentingan yang terbaik bagi anak ${ }^{14}$ yaitu semua tindakan yang menyangkut anak yang dilakukan oleh pemerintah, masyarakat, badan legeslatif, dan badan yudikatif. Dalam hal ini, anak-anak jalanan maupun anak terlantar memiliki hak yang sama untuk memperoleh perlindungan dari berbagai pihak guna menjamin tumbuh kembang serta kesehatan fisik dan mentalnya.

13 Deputi Bidang Perlindungan Anak, 2019, Buku Panduan Terminologi Perlindungan Anak dari Eksploitasi, Kementerian Pemberdayaan Perempuan dan Perlindungan Anak, Jakarta, Hlm. 18

14 Andi Muhammad dan Sofyan Andi Tenripadang, 2017, Ketentuan Hukum Perlindungan Hak Anak Jalanan Bidang Pendidikan, Jurnal Syari'ah dan Hukum Diktum, Volume 15, Nomor 2, Desember 2017, Fakultas Syariah dan Ilmu Hukum Islam Institut Agama Islam Negeri Parepare, Pare-Pare, Hlm. 232 
g. perlindungan anak dari akibat-akibat peperangan atau konflik bersenjata, perlindungan anak terhadap tindakan kekerasan.

Anak-anak yang semestinya memiliki hak untuk tumbuh kembang secara wajar ketika perang berkecamuk seluruh hak mereka bukan saja ditelantarkan, tetapi tak jarang bahkan dilanggar begitu saja tanpa sedikit pun ada rasa belas kasihan. Perang, apa pun alasannya, adalah sebuah tindak kejahatan kemanusiaan dan pelanggaran terhadap hak- hak anak yang paling brutal. $^{15}$

Perlindungan terhadap anak sebagaimana disebutkan diatas merupakan perlindungan yang tidak hanya diberikan oleh orang tua tetapi juga melibatkan berbagai unsur. Berdasarkan Pasal 20 UndangUndang Nomor 35 Tahun 2014 tentang Perubahan Atas Undang-Undang Nomor 23 Tahun 2020 tentang Perlindungan Anak bahwa kewajiban dan tanggung jawabpenyelenggara Perlindungan Anak adalah diantara :
a. Negara
b. Pemerintah
c. Pemerintah Daerah
d. Mayarakat,
e. Keluarga

\footnotetext{
${ }^{15}$ Khrisna Bayu, Anak-Anak Korban Perang, artikel 24 Februari 2016, diakses dari https://www.kemenpppa.go.id/index.php/page/rea d/31/614/anak-anak-korban-perang
}

f. Orang Tua atau Wali

Komponen tersebut harus bersinergi dalam memberikan perlindungan anak terutama terhadap anak yang terkena tindakan bullying. Corning menjelaskan bahwa sinergi sesungguhnya ada dimanamana disekitar kita termasuk di dalam diri kita dan merupakan hal yang tidak dapat dihindari. ${ }^{16}$

Sebagaimana bullying dipandang sebagai tindakan kekerasan terhadap anak, maka kekerasan tersebut dapat diklasifikasi sebagai berikut: 1) Kekerasan fisik, yang terkategorisasi meliputi menampar, menendang, memukul/meninju, mencekik, mendorong, menggigit, membenturkan, mengancam dengan benda tajam dan sebagainya; 2) kekerasan psikis, kekerasan jenis ini tidak begitu mudah untuk dikenali karena akibat yang dirasakan oleh korban tidak tampak jelas bagi orang lain. Kekerasan ini akan berpengaruh pada situasi perasaan tidak aman dan nyaman, menurunnya harga diri serta martabat korban; 3) kekerasan ekonomi, kekerasan jenis ini sangat sering terja didalam lingkungan keluarga. Kekerasan jenis ini sering terjadi ketika orang tua memaksa anak yang masih berusia dibawah umur untuk dapat memberikan kontribusi ekonomi keluarga, sehingga fenomena penjual korban,

\footnotetext{
${ }^{16}$ Husaini Usman.2011. Manajemen Teori, Praktik dan Riset Pendidikan jilid 3. Jakarta : Bumi Aksara
} 
pengamen jalanan, pengemis anak,dan lainlain kian merebak terutama diperkotaan. ${ }^{17}$

Hukum perlindungan anak di Indonesia khususnya dalam rangka memberikan perlindungan hak asasi anak yang menjadi korban kekerasan di Indonesia di masa yang akan datang harus melakukan law reform dengan tujuan untuk memberikan keadilan, kepastian, dan kemanfaatan terhadap anak di Indonesia khususnya sehingga dapat melindungi sekaligus menjamin hak-hak asasi anak yang menjadi korban kekerasan. Pemberian perlindungan hukum terhadap hak asasi anak yang menjadi korban kekerasan merupakan perlindungan terhadap harkat manusia, sehingga jaminan pemerintah terhadap pelaksanaan hak asasi anak yang menjadi korban kekerasan sudah masuk ke wilayah peradaban umat manusia. $^{18}$

Bullying baik dilakukan oleh orang dewasa maupun anak-anak dimana yang menjadi korban adalah anak, merupakan perbuatan yang tidak dapat dibenarkan dari berbagai sudut pandang. Secara individu, pelaku bullying yang dibiarkan akan tertanam menjadi sifat yang membuat seseorang terus-menerus melakukan kekerasan terhadap orang lain. Secara sosial,

\footnotetext{
${ }^{17}$ Bagong Suyanto, 20162016, Masalah Sosial Anak, cetakan ketigaJakarta: Kencana. Hlm 29-30

${ }^{18}$ Zuraidah dan Muhamad Sadi Is, 2018, Perlindungan Hukum Terhadap Hak Asasi Anak Yang Menjadi Korban Kekerasan, Jurnal Nurani, Vol. 18, No. 1 Edisi Juni 2018, Universitas Islam Negeri Raden Fatah, Palembang,hlm 160
}

pembiaran atas perilaku bullying dimasyarakat akan menjadikan bullying sebagai perilaku yang dinilai normal dimasyarakat dan menjadi hal yang biasa ketika ada seseorang atau kelompok yang melakukan kekerasan. Secara moral dan agama, perilaku bullying adalah perbuatan yang memiliki nilai negatif dan bertentangan dengan nilai ketuhanan sehingga dalam kondisi apapun tidak dapat dibenarkan.

Dalam penanganan anak yang berhadapan dengan hukum dalam kasus bullying dapat dilakukan upaya diversi, sebagaimana diatur dalam Pasal 1 angka Undang-Undang Nomor 11 Tahun 2012 tentang Sistem Peradilan Anak, yaitu upaya pengalihan penyelesaian perkara anak dari proses peradilan pidana ke proses di luar peradilan pidana. Konsep diversi ini berlandas pada hukum restoratif. Anak sebagai korban, fokus utama pendekatan restoratif terletak pada pemulihan dan kompensasi kerugian. Dalam proses mediasi, korban dan pelaku harus didampingi orangtua atau wali, pembimbing kemasyarakatan (PK), dan pekerja sosial profesional. Namun, penerapan atau pelaksanaan proses diversi tidak dapat terhadap semua anak yang melakukan atau semua jenis tindak pidana yang dilakukan oleh anak, sehingga penyidik dalam melakukan diversi harus memper-timbangkan kategori tindak pidana dan umur anak. 
Dalam kondisi tersebut, hukum memegang peranan untuk memberikan kepastian hukum terhadap anak yang menjadi korban bullying. Dengan adanya ketentuan hukum, hal ini dapat memberikan perlindungan terhadap kedua pihak, baik pelaku maupun korban, dengan tujuan memperoleh keadilan yang sesuai yang dapat dimaknai bahwa korban terlindungi dan mendapatkan kepastian hukum. Disisi lain, pelaku mendapatkan sanksi yang sesuai atas perbuatannya namun tetap terjamin hak asasinya selama menjalani hukuman yang ditetapkan atas perbuatannya.

\section{KESIMPULAN}

Perkembangan pergaulan di lingkungan remaja saat ini perlu perhatian yang sangat ketat. Peran keluarga melalui orang tua, lingkngan sekolah bahkan lingkungan masyarakat merupakan ujung tonggak untuk memberikan perhatian kepada anak. Anak terlah dilindungi oleh peaturan perundang-undangan, dimana anak tidak boleh untuk dilakukan secara diskriminasi dalam lingkungan. Pemenuhan hak anak saat ini masih menjadi masalah besar dikarenakan banyaknya tindakan diskriminasi atau bahkan tindakan kekerasan. Tindakan kekerasan kepada anak yang sering dikenal dengan bullyingbanyak sekali kejadian di lingkungan anak. Per- lakuan bullying ini dapat mengakibatkan masalah bagi pelaku ataupun korban, dimana pelaku bullying senantiasa merasa bangga karena tindakannya hal ini berbeda dengan korban. Korban tindakan bullying yang terjadi lingkungan sekolah maupun di sekolah memberikan dampak baik psikis maupun fisik. Korban bullying harus diberikan perlindungan agar tidak menjadi korban lagi sehingga hukum perlindungan anak di Indonesia khususnya dalam rangka memberikan perlindungan. Hak asasi anak yang menjadi korban kekerasan di Indonesia di masa yang akan datang harus melakukan law reform dengan tujuan untuk memberikan keadilan, kepastian, dan kemanfaatan terhadap anak di Indonesia khususnya sehingga dapat melindungi sekaligus menjamin hak-hak asasi anak yang menjadi korban kekerasan. Pemberian perlindungan hukum terhadap hak asasi anak yang menjadi korban kekerasan merupakan perlindungan terhadap harkat manusia, sehingga jaminan pemerintah terhadap pelaksanaan hak asasi anak yang menjadi korban kekerasan sudah masuk ke wilayah peradaban umat manusia 


\section{DAFTAR PUSTAKA}

Abintoro Prakoso, Hukum Perlindungan

Anak, Fakultas Hukum Universitas

Jember, Jember, 2015.

Abintoro Prakoso, Pembaruan Sistem

Peradilan Pidana Anak, Yogyakarta,

Laksbang Grafika, 2013.

Andi Muhammad dan Sofyan Andi Tenripadang, Ketentuan Hukum Perlindungan Hak Anak Jalanan Bidang Pendidikan,

Bagong Suyanto, Masalah Sosial Anak, cetakan ketiga, Kencana, Jakarta:. 2016

Barda Nawawi, Beberapa Aspek Kebijakan Penegakan dan Pengembangan Hukum Pidana, Citra Aditya Bakti, Bandung, 1998.

Deputi Bidang Perlindungan Anak, Buku Panduan Terminologi Perlindungan Anak dari Eksploitasi, Kementerian Pemberdayaan Perempuan dan Perlindungan Anak, Jakarta, 2019.

Gatot Soepromono, Hukum Acara Pengadilan Anak, PT Djambatan, Jakarta, 2000.
Haynie, D. L dkk, "Bullies, Victims, and Bully/Victims: Distinct Groupsof AtRisk Youth, 2001.

Husaini Usman.. Manajemen Teori, Praktik dan Riset Pendidikan jilid 3. Jakarta : Bumi Aksara, 2011.

Jurnal Syari'ah dan Hukum Diktum, Volume 15, Nomor 2, 2017, Fakultas Syariah dan Ilmu Hukum Islam Institut Agama Islam Negeri Parepare, Pare-Pare,

Mallon, Gerald P and Peg McCartt Hess. (2005). Child Welfare For The Twenty-First Century. A Handbook of Practices, Policies, and Program. Columbia University Press.

Mohammad Taufik Makarao dkk, Hukum Perlindungan Anak dan Penghapusan Kekerasan dalam Rumah Tangga, Rineka Cipta, Jakarta, 2013.

Muladi dan Barda Nawawi, Teori-Teori dan Kejahatan Hukum Pidana, Alumni, Bandung, 2005.

Peter Mahmud Marzuki, Penelitian Hukum,Kencana Prenada Media, Jakarta, 2011. 
Salim HS,dkk, Penerapan Teori Hukum Pada Tesis dan Desertasi,Raja Grafindo Persada, Jakarta, 2013.

Soerjono Soekanto dan Sri Mamudji, Penelitian Hukum Normatif (Suatu Tinjauan Singkat), RajaGrafindo Persada, cetakan ke-16, Jakarta, 2014.

Zuraidah dan Muhamad Sadi Is, Perlindungan Hukum Terhadap Hak Asasi Anak Yang Menjadi Korban Kekerasan, Jurnal Nurani, Vol. 18, No. 1 Edisi Juni 2018, Universitas Islam Negeri Raden Fatah, Palembang,

\section{Perundang-undangan :}

Undang-Undang Dasar Negara Republik Indonesia Tahun 1945

Undang-Undang Republik Indonesia Nomor 4 Tahun 1979 tentang Kesejahteraan Anak
Undang-Undang Nomor 11 Tahun 2012 tentang Sistem Peradilan Anak

Undang-Undang Nomor 35 Tahun 2014 tentang Perubahan Atas UndangUndang Nomor 23 Tahun 2020 tentang Perlindungan Anak

\section{Internet :}

https://www.kemenpppa.go.id/index.php/pa ge/read/31/614/anak-anak-korbanperang

http://tesishukum.com/pengertianperlindungan-hukum-menurut-para$\underline{\text { ahli/ }}$ 


\section{BIODATA SINGKAT PENULIS}

Sari Damayanti adalah Dosen di Program Studi S1 Ilmu Hukum Fakultas Humaniora dan Kesehatan Universitas Mulia Balikpapan sejak tahun 2019. Memperoleh Gelar Sarjana bidang Hukum di Universitas Balikpapan tahun 2007 dan Memperoleh Gelar Magister Hukum di Universitas Balikpapan tahun 2017. Sari Damayanti dapat di hubungi di nomor 081254899699

email sari.d@universitasmulia.ac.id

Okta Nofia Sari adalah Dosen di Program Studi S1 Ilmu Hukum Fakultas Humaniora dan Kesehatan Universitas Mulia Balikpapan sejak tahun 2019. Memperoleh Gelar Sarjana bidang Hukum di Universitas Jember tahun 2013 dan Memperoleh Gelar Magister Hukum di Universitas Jember. Okta Nofia Sari dapat di hubungi di nomor 081336524818 atau email Oktanofia@universitasmulia.ac.id
Kesuma Bagaskara adalah mahasiswa Program Studi s1 Ilmu Hukum Fakultas Humaniora dan Kesehatan Universitas Mulia Balikpapan angkatan 2019. Kesuma Bagaskara dapat di hubungi di nomor 089686176545 atau emailkesumabagaskara@students.universita $\underline{\text { smulia.ac.id }}$ 